\title{
Genetically Distinct Acidovorax citrulli Strains Display Cucurbit Fruit Preference Under Field Conditions
}

\author{
Mei Zhao, ${ }^{1}$ Bhabesh Dutta, ${ }^{2}$ Xuelin Luo, ${ }^{3}$ Saul Burdman, ${ }^{4}$ and Ron Walcott $1, \dagger$ \\ ${ }^{1}$ Department of Plant Pathology, University of Georgia, Athens, GA 30602, U.S.A. \\ 2 Department of Plant Pathology, University of Georgia, Tifton, GA 31793, U.S.A. \\ ${ }^{3}$ Experimental Statistics, University of Georgia, Tifton, GA 31793, U.S.A. \\ ${ }^{4}$ Department of Plant Pathology and Microbiology, The Robert H. Smith Faculty of Agriculture, Food and Environment, The Hebrew University \\ of Jerusalem, Rehovot 76100, Israel \\ Accepted for publication 18 February 2020.
}

\begin{abstract}
Strains of Acidovorax citrulli, the causal agent of bacterial fruit blotch (BFB) of cucurbits, can be assigned to two groups, I and II. The natural association of group I and II strains with different cucurbit species suggests host preference; however, there are no direct data to support this hypothesis under field conditions. Hence, the objective of this study was to assess differences in the prevalence of group I and II A. citrulli strains on cucurbit species in the field. From 2017 to 2019, we used group I and II strains to initiate BFB outbreaks in field plots planted with four cucurbit species. At different times, we collected

I strains were $21.7,11.5$, and 22.1 times greater, respectively, than the odds of watermelon foliage infection by the group I strain $(P<0.0001)$. More strikingly, the odds of melon fruit infection by the group I strain were 97.5 times greater than watermelon fruit infection by the same strain $(P<0.0001)$. Unexpectedly, some of the group II isolates recovered from the 2017 and 2019 studies were different from the group II strains used as inocula. Overall, data from these experiments confirm that $A$. citrulli strains exhibit a preference for watermelon and melon, which is more pronounced in fruit tissues.
\end{abstract} symptomatic tissues and assayed them for group I and II strains using a group-specific PCR assay. Binary distribution data analysis revealed that the odds of melon, pumpkin, and squash foliage infection by group
Keywords: Acidovorax citrulli, bacteriology, host preference, watermelon fruit blotch
Bacterial fruit blotch (BFB) is an economically important seedborne and seed-transmitted disease of cucurbitaceous plant species including watermelon (Citrullus lanatus (Thunb.) Matsum. \& Nakai) and melon (Cucumis melo L.). Acidovorax citrulli, the causal agent of BFB, was first isolated by Webb and Goth in 1965 at the Regional Plant Introduction Station in Griffin, Georgia, U.S.A. (Webb and Goth 1965). However, it was not until 1987 that the first natural BFB outbreak occurred in the Mariana Islands on watermelon (Wall and Santos 1988). In 1989 the disease was observed in commercial watermelon fields in Florida (Somodi et al. 1991) and Indiana (Latin and Rane 1990). Subsequently, BFB outbreaks have occurred in many regions around the world, primarily on watermelon and melon crops, resulting in significant economic losses (Burdman and Walcott 2012).

A. citrulli can survive to varying degrees on plant tissues and substrates, e.g., weeds, volunteer seeds, plant and fruit debris, and planting trays. In the greenhouse, high plant densities, high relative humidity, and overhead irrigation are highly conducive for the development and spread of BFB. Generally, cucurbit seedlings are inspected for BFB symptoms before transplanting to the field. However, symptomless but latently infected seedlings may escape detection and serve as inoculum sources in the field. In general, warm humid conditions favor BFB development under field conditions and prolonged leaf wetness, and overhead irrigation or

†Corresponding author: R. Walcott; rwalcott@uga.edu

Funding: This work was funded by the United States-Israel Binational Agricultural Research and Development Fund (grant IS-5023-17C), the University of Georgia Graduate School Summer Research Travel grants program (2017-2019), and 2019 American Phytopathological Society Raymond J. Tarleton Student Fellowship.

The author(s) declare no conflict of interest.

C 2020 The American Phytopathological Society frequent rainfall promote pathogen dispersal and bacterial ingress into plant tissues via open stomata or wounds (Zhao and Walcott 2018).

BFB has a wide host range in the family Cucurbitaceae (Zhao and Walcott 2018). Watermelon and melon are highly susceptible, and as mentioned above, most BFB outbreaks have been reported on these species. However, other hosts include cucumber (Cucumis sativus L.) (Martin et al. 1999), gramma (Cucurbita moschata) (Martin and Horlock 2002), squash and pumpkin (Cucurbita pepo, Cucurbita maxima, and Cucurbita moschata) (Langston et al. 1999), citron melon (Citrullus lanatus var. citroides) (Isakeit et al. 1998), prickly paddymelon (Cucumis myriocarpus subsp. myriocarpus) (O'Brien and Martin 1999), and several types of gourds.

A. citrulli strains can be divided into two major groups, I and II, based on carbon substrate utilization (Walcott et al. 2004), DNA fingerprint analyses by pulse field gel electrophoresis (PFGE) (Burdman et al. 2005; Walcott et al. 2000; Yan et al. 2013), repetitive extragenic palindromic-polymerase chain reaction (repPCR) (Walcott et al. 2004), multilocus sequence analysis (MLSA) (Feng et al. 2009; Yan et al. 2013), and fatty acid methyl ester analysis (Walcott et al. 2000). The diversity of A. citrulli was initially reported in an Australian population by O'Brien and Martin (1999). Carbon substrate utilization profiles and pathogenicity assays were employed to characterize strains recovered from several cucurbit hosts including watermelon, rockmelon, honeydew (Cucumis melo var. indorus Jacq.), and prickly paddymelon. Carbon substrate utilization profile analysis separated the strains into two groups. One group recovered from rockmelon and honeydew failed to utilize L-leucine, but utilized 2-amino ethanol. The other group, recovered from watermelon, utilized L-leucine, but were unable to utilize 2-amino ethanol.

Walcott et al. (2000) first reported two genetically distinct groups of $A$. citrulli among 120 strains collected from a broad range of geographical origins and a range of cucurbitaceous plants. In 2005, 
a study on an A. citrulli population from Israel yielded similar results (Burdman et al. 2005). Using MLSA, Feng et al. (2009) showed that $65 \%(33 / 51)$ of the A. citrulli strains from China belonged to group I. Similarly, Yan et al. (2013) reported two A. citrulli groups in China with $63 \%$ (71/112) of the tested strains being members of group I. More recently, 97\% (72/74) of a Brazilian population of $A$. citrulli strains, recovered predominantly from melon, were found to be members of group I (Silva et al. 2016). This indicated a predominance of group I strains in Brazil.

The natural association of group I and II A. citrulli strains with different cucurbit species strongly suggests host preference. In 1999, O'Brien and Martin observed that $A$. citrulli strains recovered from rockmelon production regions (North Queensland, Australia) were equally virulent on watermelon and rockmelon seedlings. However, strains collected from watermelon production regions (South Queensland, Australia) were more virulent on watermelon than rockmelon seedlings (O'Brien and Martin 1999). In 2000, Walcott et al. reported that $85 \%(17 / 20)$ of group I $A$. citrulli strains were isolated from cantaloupe and pumpkin, while $65 \%(65 / 100)$ of group II strains were isolated from watermelon, $34 \%$ from citron, and $1 \%$ from cantaloupe (Walcott et al. 2000).

In a subsequent report using $A$. citrulli strains representing a wider geographical distribution, Walcott et al. (2004) reported a similar host preference pattern. More specifically, 93\% (27/29) of group II strains were isolated from watermelon, and in contrast, 85\% (29/34) of group I strains were isolated from muskmelon, bitter gourd (Momordica charantia), rockmelon, pumpkin, honeydew, and melon. Additionally, an MLSA study of a global A. citrulli strain collection supported the hypothesis of A. citrulli host preference (Feng et al. 2009). Of the strains with known hosts of origin, 88\% (36/41) from group II were collected from watermelon, while $51 \%(24 / 47)$ of the group I strains were recovered from nonwatermelon cucurbit species (Feng et al. 2009). In agreement with these observations, Yan et al. (2013) reported that among a collection of 118 Chinese A. citrulli strains, 92\% (67/73) of the strains belonging to group I were isolated from melon, while $93 \%$ (42/45) of the group II strains were recovered from watermelon. To further support the hypothesis of host preference between group I and II A citrulli strains, Walcott et al. (2000) reported that in a BFB outbreak in a mixed planting of pumpkins and watermelons in Georgia, USA, only pumpkin fruits displayed BFB symptoms. In this study, only group I strains were isolated from the symptomatic pumpkin fruits.

Despite the data suggesting host preference, Walcott et al. (2004) conducted greenhouse seedling and fruit inoculation assays and reported that representative group I and II A. citrulli strains could infect a range of cucurbit species, with no clear evidence for strict host specificity. In agreement with this study, Zivanovic and Walcott (2017) reported that there were no significant differences in temporal bacterial population dynamics between A. citrulli group I strain M6 and group II strain AAC00-1 after cotyledon tissue infiltration with bacterial cell suspensions at $10^{4}$ colony forming units $(\mathrm{CFU}) / \mathrm{ml}$. It is possible that there are differences in host preference between group I and II $A$. citrulli strains under natural field conditions, but artificial inoculation techniques may prevent the observation of this phenotype. Therefore, further studies using natural inoculation and pathogen spread under field conditions are needed to elucidate differences in host preference of $A$. citrulli groups.

Yan et al. (2017) recently developed a detached melon fruit assay that clearly distinguished representative group I and II A. citrulli strains based on symptom development. Using this assay, they observed a consistent difference in pathogenicity between group I and II $A$. citrulli strains in the fruit (Yan et al. 2017). Based on these observations, we hypothesized that A. citrulli host preference manifests more strongly in cucurbit fruits than in foliar tissues. Consequently, the objective of this study was to assess differences in cucurbit host preference in foliar and fruit tissues between group I and II $A$. citrulli strains under field conditions.

\section{MATERIALS AND METHODS}

Bacterial strains and growth condition. Naturally occurring, antibiotic-resistant strains of representative group I (AAC2031RR1, resistant to rifampicin) and II (AAC94-21SR1, resistant to streptomycin) A. citrulli were selected as inocula. These strains represent the most prevalent haplotypes of group I (B5) and II (A3) strains that were recovered from China, and Georgia U.S.A., respectively (Silva et al. 2016). The A. citrulli group II strain 17-6 was isolated from a field trial that we conducted in 2017, and it was used as an additional group II inoculum strain in 2019. For plant inoculation, strains were cultured overnight in nutrient broth (Becton Dickinson, Sparks, MD) at $28^{\circ} \mathrm{C}$ on a rotary shaker (New Brunswick Scientific, Edison, NJ) at $200 \mathrm{rpm}$, adjusted to an optical density at $600 \mathrm{~nm}\left(\mathrm{OD}_{600}\right)$ of $0.3\left(\sim 10^{8} \mathrm{CFU} / \mathrm{ml}\right)$ spectrophotometrically (Spectronic 20; Bausch and Lomb, Rochester, NY), and diluted to the desired concentration using sterilized distilled water $\left(\mathrm{sdH}_{2} \mathrm{O}\right)$. When required, media were supplemented with the following antibiotics: rifampicin $(100 \mu \mathrm{g} / \mathrm{ml})$ and streptomycin $(100 \mu \mathrm{g} / \mathrm{ml})$.

Field experiment design. Watermelon ('Crimson Sweet') (Johnny's Selected Seeds, Winslow, ME), melon ('Joaquin Gold') (Rogers Brand, Syngenta, Greensboro, NC), squash ('Golden Summer Crookneck') (Wild West Seed, Albany, OR), and pumpkin ('Jack O' Lantern') (Dorsing Seeds Inc., Nyssa, OR) seedlings were grown in 36-cell plastic trays (Grower's Solution, LLC, Cookeville, $\mathrm{TN}$ ) in a commercial potting mix (Sungro Horticulture, Agawam, MA) under standard greenhouse conditions for 4 weeks. Thirty-four healthy seedlings for each cucurbit crop were transplanted to a field plot on raised beds in Tifton, GA. Each cucurbit plot consisted of five rows of plants with 10 plants per row, and each row was $6.1 \mathrm{~m}$ long with $0.6 \mathrm{~m}$ plant spacing. The distance between plots was approximately $1.8 \mathrm{~m}$ and the distance between rows was approximately $2.4 \mathrm{~m}$. Concurrently, 2-week-old melon and watermelon seedlings that were spray-inoculated with $10^{6} \mathrm{CFU} /$ $\mathrm{ml}$ of $A$. citrulli strains AAC203-1-RR1 and AAC94-21SR1, respectively, were transplanted into the field plots. Sixteen inoculated seedlings that displayed typical BFB symptoms were placed at the middle and edges of each plot of each cucurbit species. In each plot, we transplanted eight melon seedlings inoculated with an $A$. citrulli group I strain, and eight watermelon seedlings inoculated with A. citrulli group II strain(s). These inoculated seedlings served as inoculum sources for natural BFB epidemics. Irrigation was applied through three automated overhead sprinkler systems (Strongway Tripod Sprinkler, Northern Tool + Equipment, Burnsville, MN) twice a week for $1 \mathrm{~h}$ each time. Leaves with BFB symptoms were collected from each plot at three sampling times over a 3- to 4-week period. Additionally, all cucurbit fruits that developed BFB symptoms were collected. This study was conducted three times from 2017 to 2019, and in the 2019 experiment, watermelon seedlings were spray-inoculated with A. citrulli $94-21$ SR1 and the group II field isolate 17-6, recovered from the 2017 trial. The two group II strains were inoculated separately. For each plot, four watermelon seedlings inoculated with strain 94-21SR1 and four watermelon seedlings inoculated with strain 17-6 were transplanted to the field in 2019. Total DNA was extracted from the BFB lesion of each sample using the Synergy 2.0 Plant DNA Extraction Kit (OPS Diagnostics LLC, Lebanon, NJ). DNA samples were used as templates to detect A. citrulli and to determine whether the strain belonged to group I or II by an A. citrulli group-specific polymerase chain reaction (PCR) assay. To efficiently accomplish this task, we developed a duplex PCR assay with primer sets that were specific for group I and II A. citrulli strains (described below). To ensure that PCR-negative results were not due to inhibitory compounds coextracted with DNA, DNA samples were 10-fold diluted and subjected to a second round of PCR. If the results were still negative, DNA samples were further diluted 100-fold and subjected to a third round of PCR. Field studies were conducted at the University of Georgia Tifton 
Vegetable Park farm in Tifton, GA in 2017 (one plot), 2018 (two plots), and 2019 (two plots).

Development of a duplex PCR assay to rapidly distinguish group I and II $\boldsymbol{A}$. citrulli strains. To rapidly detect the presence of $A$. citrulli in symptomatic plant tissues and to determine the group to which each strain belonged, we developed a duplex PCR assay with group-specific primer sets (Table 1). Primers for this assay were designed using the Primer 3 program (Kõressaar et al. 2018) based on genes APS58_3303 (gene ID according to the M6 annotation; GenBank accession CP029373.1 (Yang et al. 2019a)) and Aave_2708 (gene ID according to the AAC00-1 annotation; GenBank accession CP000512.1), which were present only in group I and II strains, respectively (Eckshtain-Levi et al. 2014; Jiménez Guerrero et al. 2019). PCR was conducted using OneTaq DNA polymerase according to the manufacturer's instructions (New England Biolabs Inc., Ipswich, MA). The sensitivity of the duplex PCR assay was evaluated using DNA from 10-fold serial dilutions of boiled cells of A. citrulli group I strain AAC203-1RR1 and group II strain AAC94-21SR1. The specificity of the PCR assay was evaluated using DNA from boiled cells $\left(10^{8} \mathrm{CFU} / \mathrm{ml}\right)$ of group I $(n=9)$ and group II $(n=10)$ A. citrulli strains (Table 2). Cell suspensions of each strain were generated by suspending bacterial cells from overnight cultures in $\mathrm{sdH}_{2} \mathrm{O}$. The concentration of each cell suspension was adjusted to $\mathrm{OD}_{600}=0.3$ $\left(\sim 10^{8} \mathrm{CFU} / \mathrm{ml}\right)$ and a $1-\mathrm{ml}$ aliquot was lysed by incubating at $100^{\circ} \mathrm{C}$ for $10 \mathrm{~min}$ to release genomic DNA. Samples of $2.5 \mu \mathrm{l}$ of lysed cells were used as templates for PCR assays with the following thermal profile: $94^{\circ} \mathrm{C}$ for $5 \mathrm{~min}$; 35 cycles of $94^{\circ} \mathrm{C}$ for 30 $\mathrm{s}, 55^{\circ} \mathrm{C}$ for $30 \mathrm{~s}$, and $68^{\circ} \mathrm{C}$ for $30 \mathrm{~s}$; and then a final extension of $68^{\circ} \mathrm{C}$ for $5 \mathrm{~min}$. Products were separated by electrophoresis on $1 \%$ agarose gels stained with ethidium bromide $(0.5 \mu \mathrm{l} / \mathrm{ml})$ and in $1 \times$ Tris-acetate-EDTA buffer for $30 \mathrm{~min}$ at $120 \mathrm{~V}$.
DNA fingerprinting of representative field isolates. Bacterial isolation was performed from selected leaf and fruit tissues on King's B medium (King et al. 1954) to confirm the presence and viability of the $A$. citrulli isolates detected by PCR. To test if the group I and II $A$. citrulli isolates causing BFB symptoms in the field were identical to those used for inoculation, DNA restriction digestion with SpeI (NEB) followed by PFGE was conducted on representative field isolates (Table 3) from $2017(n=8), 2018(n=6)$, and $2019(n=8)$ as previously described (Walcott et al. 2000).

Statistical analysis. For each cucurbit species, the data were expressed as the presence of group I and II A. citrulli members detected from symptomatic foliar and fruit lesions. We used the GLIMMIX (SAS V9.4; SAS Institute, Cary, NC) procedure on the leaf and fruit tissue types for binary distribution data, and the odds ratios were calculated using a logit link function. As BFB-infected squash fruits were detected only in 1 year, data from watermelon and melon fruits were used for comparisons at the fruit tissue type level.

\section{RESULTS}

Development of a duplex PCR assay to distinguish group I and II A. citrulli strains. We developed a new duplex PCR assay to distinguish the two groups of $A$. citrulli in a single reaction. The detection thresholds of the group I- and II-specific PCR assays based on primer sets, 550-34F/550-626R and 2708-225F/2708-433R were $10^{7}$ and $10^{6} \mathrm{CFU} / \mathrm{ml}$, respectively (Fig. 1). With regards to specificity, the group I primer set amplified DNA from all nine group I strains tested, but yielded no amplicons with DNA from boiled cells from 10 group II strains (Table 2). In contrast, the group II primer set amplified DNA from all 10 group II strains tested, but yielded no amplicon with DNA from the nine group I strains (Table 2).

TABLE 1. List of primers used in this study

\begin{tabular}{|c|c|c|c|c|}
\hline Primer designation & Sequence $\left(5^{\prime}-3^{\prime}\right)$ & Group & Target gene & Amplicon size (bp) \\
\hline $550-34 \mathrm{~F}$ & TCATCGCCAACCGTTACACA & I & APS58_3303a & 593 \\
\hline $550-626 \mathrm{R}$ & CTCCACGAGTCGAGAACCAC & & & \\
\hline $2708-225 \mathrm{~F}$ & GCTGTTAGCCAACTCCCTGT & II & Aave_2708 & 209 \\
\hline 2708-433R & TAGGCGAGTCAAAGTGCTGG & & & \\
\hline
\end{tabular}

${ }^{a}$ Based on the annotation of the Acidovorax citrulli M6 chromosome (GenBank accession CP029373.1).

${ }^{b}$ Based on the annotation of the A. citrulli AAC00-1 chromosome (GenBank accession CP000512.1).

TABLE 2. Specificity of Acidovorax citrulli group I- and II-specific oligonucleotide primers as determined by PCR assay ${ }^{\mathrm{a}}$

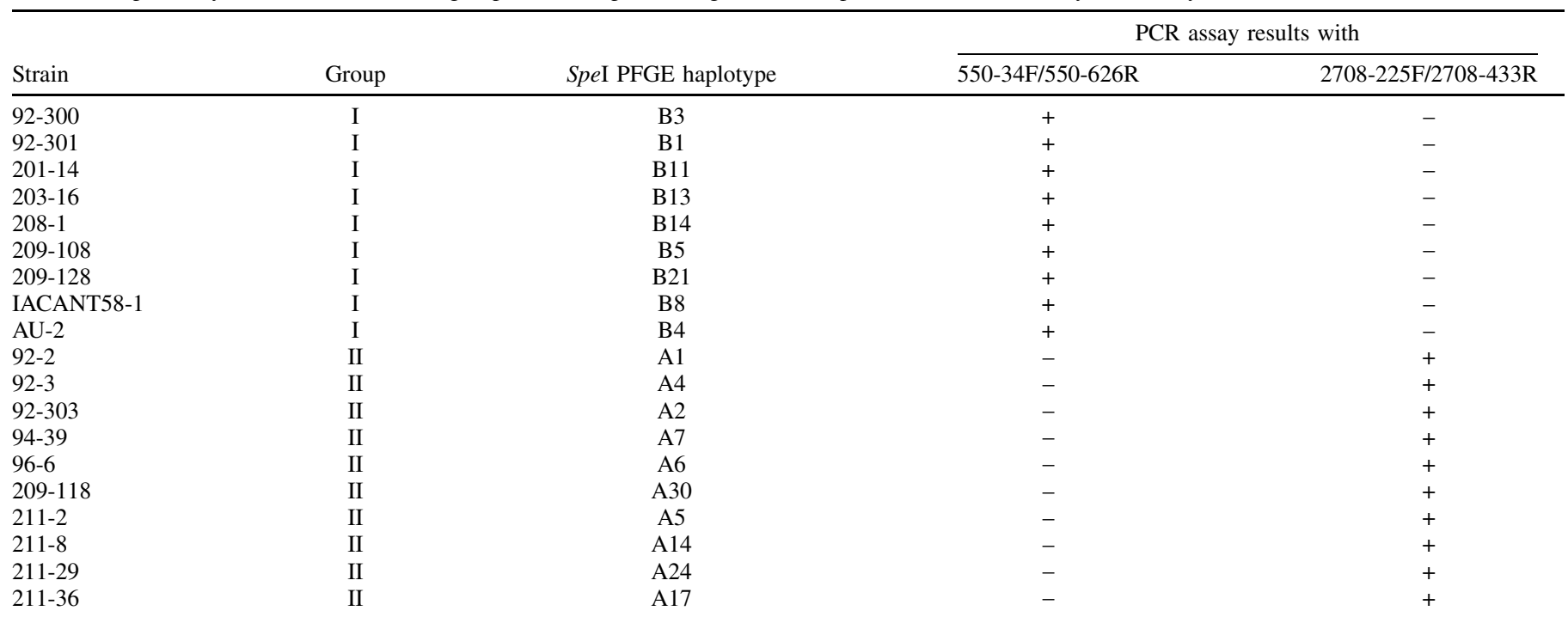

$\mathrm{a}+$ and - indicate the presence or absence of a 593- or a 209-bp band resulting from conventional PCR using primer sets 550-34F/550-626R and 2708-225F/2708433R, respectively. Strain source: R. Walcott collection. 
Field experiments to investigate $A$. citrulli cucurbit host preference. 2017 field study. During the field study, total precipitation was $20.85 \mathrm{~cm}$ and average rainfall per day was $0.41 \mathrm{~cm}$. The average temperature during the field study was $26.1^{\circ} \mathrm{C}$ (Table 4). In total, $37 \%$ (11/30) of watermelon leaf samples that exhibited visible BFB symptoms were infected with the group I strain, while $60 \%(15 / 25)$ of symptomatic melon leaf samples were infected with the group I strain. Additionally, 67\% (4/6) of symptomatic pumpkin and $71 \%(10 / 14)$ of symptomatic squash leaf samples were infected with the group I strain (Fig. 2A). For fruits, none of the pumpkin or squash fruit samples with putative BFB lesions were determined to be positive for A. citrulli by PCR assay. On the other hand, $100 \%$ (9/9) of the symptomatic watermelon fruit samples were determined to be infected with the group II strain. With regards to symptomatic melon fruits, $86 \%$ $(6 / 7)$ were determined to be infected with the group I strain (Fig. 2B)

2018 field study. During the field study, total precipitation was $26.59 \mathrm{~cm}$ and average rainfall per day was $0.44 \mathrm{~cm}$. The average temperature during the field study was $25.6^{\circ} \mathrm{C}$ (Table 4). In total, $42 \%(28 / 67)$ of the watermelon leaf samples that exhibited BFB symptoms were infected with the group II strain, while $100 \%$ of symptomatic melon $(n=80)$, pumpkin $(n=2)$, and squash $(n=19)$ leaf samples were infected with the group I strain (Fig. 3A). For fruit samples, no putative pumpkin or squash fruit lesions were determined to be positive for $A$. citrulli by PCR assay. On the other hand, $100 \%(n=20)$ of the symptomatic melon fruit samples were infected with the group I strain. Interestingly, in 2018, only two infected watermelon fruits were observed and both were infected with the group I strain (Fig. 3B).

2019 field study. During the field study, total precipitation was $18.62 \mathrm{~cm}$ and average rainfall per day was $0.31 \mathrm{~cm}$. The average temperature during the field study was $25.4^{\circ} \mathrm{C}$ (Table 4). Seven percent $(5 / 69)$ of infected watermelon leaf samples were determined to be infected with the group I strain, while $82 \%$ (75/92) of symptomatic melon leaf samples were infected with the group I strain. Additionally, $100 \%$ (5/5) of the BFB-infected squash leaf samples were infected with the group I strain (Fig. 4A). No pumpkin leaves or fruit samples tested positive for $A$. citrulli by PCR assay. In contrast, $95 \%(36 / 38)$ of the symptomatic watermelon fruit samples were determined to be infected with group II by PCR assay. With regards to symptomatic melon fruits, 78\% (7/9) were infected with the group I strain (Fig. 4B). For the first time in 2019, we observed squash fruits with BFB symptoms and 100\% (5/5) of these fruits were infected with the group I strain.

Genetic analysis of $A$. citrulli isolates recovered from field plots. All group I A. citrulli field isolates had SpeI-PFGE profiles that were identical to the strain used for inoculation (AAC2031RR1) (Fig. 5). Additionally, the recovered isolates were resistant to rifampicin as expected. In contrast, the 2017 group II field isolates had two SpeI-PFGE profiles that were both different from that of the group II strain used for inoculation (AAC94-21SR1) (Fig. 5). Moreover, these isolates were sensitive to streptomycin, indicating that they occurred naturally in the environment. The 2018 group II field isolates recovered were genetically identical to the strain used for inoculation (AAC9421SR1) based on SpeI-PFGE analysis (Fig. 5). The 2019 group II field

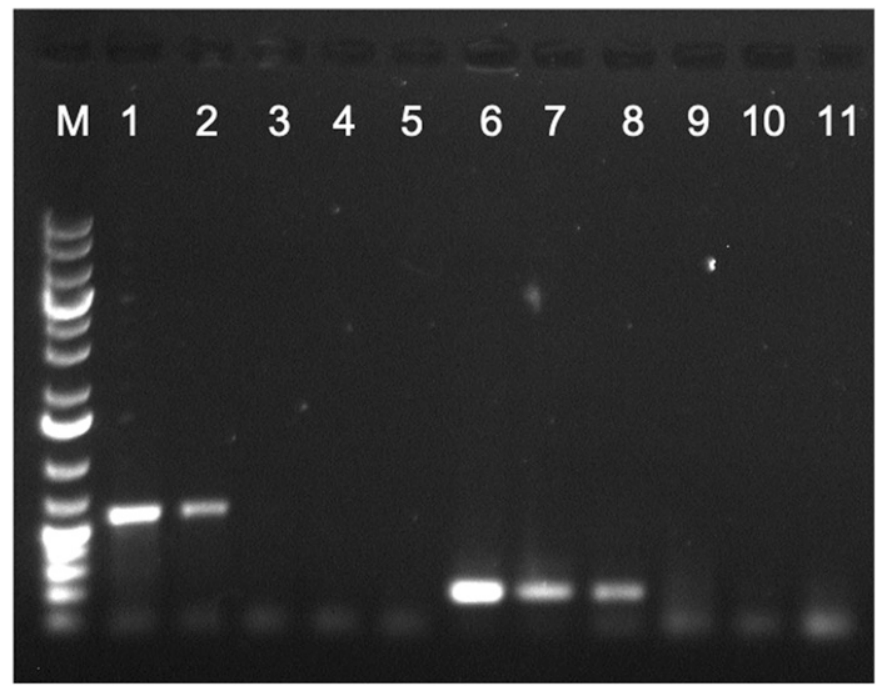

Fig. 1. Detection sensitivity of group I (550-34F/550-626R)- and II (2708225F/2708-433R)-specific PCR assays for Acidovorax citrulli strains based on 10-fold serial dilutions of bacterial cell suspensions. Lane M: GeneRuler $1 \mathrm{~kb}$ Plus DNA Ladder; lane 1: AAC203-1RR1, $10^{8}$ CFU/ml; lane 2: AAC203-1RR1, $10^{7} \mathrm{CFU} / \mathrm{ml}$; lane 3: AAC203-1RR1, $10^{6} \mathrm{CFU} / \mathrm{ml}$; lane 4: AAC203-1RR1, $10^{5}$ $\mathrm{CFU} / \mathrm{ml}$; lane 5: AAC203-1RR1, $10^{4} \mathrm{CFU} / \mathrm{ml}$; lane 6: AAC94-21SR1, $10^{8} \mathrm{CFU} /$ $\mathrm{ml}$; lane 7: AAC94-21SR1, $10^{7} \mathrm{CFU} / \mathrm{ml}$; lane 8: AAC94-21SR1, $10^{6} \mathrm{CFU} / \mathrm{ml}$; lane 9: AAC94-21SR1, $10^{5} \mathrm{CFU} / \mathrm{ml}$; lane 10: AAC94-21SR1, $10^{4} \mathrm{CFU} / \mathrm{ml}$; and lane 11: $\mathrm{H}_{2} \mathrm{O}$ negative control.

TABLE 3. List of Acidovorax citrulli isolates analyzed by SpeI-digested pulse field gel electrophoresis (PFGE)

\begin{tabular}{|c|c|c|c|c|c|c|c|}
\hline Isolate & Sample date & Host & Tissue & PFGE group & PFGE profile & Rifampicin resistance & Streptomycin resistance \\
\hline $17-1$ & $7 / 4 / 2017$ & Watermelon & Fruit & II & 2 & + & - \\
\hline $17-2$ & $7 / 4 / 2017$ & Melon & Fruit & II & 2 & + & - \\
\hline $17-3$ & $6 / 19 / 2017$ & Melon & Leaf & I & 1 & + & - \\
\hline $17-4$ & $6 / 19 / 2017$ & Watermelon & Leaf & I & 1 & + & - \\
\hline $17-5$ & $7 / 12 / 2017$ & Watermelon & Fruit & II & 3 & + & - \\
\hline $17-6$ & $7 / 12 / 2017$ & Watermelon & Fruit & II & 2 & + & - \\
\hline $17-7$ & $7 / 12 / 2017$ & Watermelon & Fruit & II & 3 & + & - \\
\hline $17-8$ & $7 / 20 / 2017$ & Melon & Fruit & I & 1 & + & - \\
\hline $18-1$ & $5 / 22 / 2018$ & Melon & Leaf & I & 1 & + & - \\
\hline $18-3$ & $5 / 22 / 2018$ & Watermelon & Leaf & I & 1 & + & - \\
\hline $18-8$ & $5 / 22 / 2018$ & Watermelon & Leaf & II & 4 & + & + \\
\hline $18-18$ & $6 / 1 / 2018$ & Watermelon & Leaf & II & 4 & + & + \\
\hline $18-19$ & $6 / 22 / 2018$ & Watermelon & Fruit & I & 1 & + & - \\
\hline $18-20$ & $6 / 22 / 2018$ & Melon & Fruit & I & 1 & + & - \\
\hline $19-2$ & $6 / 1 / 2019$ & Watermelon & Fruit & II & 2 & + & - \\
\hline $19-3$ & $6 / 1 / 2019$ & Melon & Fruit & I & 1 & + & - \\
\hline $19-4$ & $6 / 1 / 2019$ & Melon & Leaf & II & 2 & + & - \\
\hline $19-5$ & $6 / 1 / 2019$ & Watermelon & Leaf & II & 5 & + & - \\
\hline $19-7$ & $6 / 1 / 2019$ & Melon & Leaf & I & 1 & + & - \\
\hline $19-8$ & $6 / 1 / 2019$ & Melon & Leaf & I & 1 & + & - \\
\hline $19-10$ & $6 / 13 / 2019$ & Melon & Fruit & I & 1 & + & - \\
\hline $19-13$ & $6 / 21 / 2019$ & Watermelon & Fruit & II & 2 & + & - \\
\hline
\end{tabular}


isolates $(n=4)$ were identical to the strain used for inoculation (17-6), with one exception (AAC strain 19-5) (Fig. 5).

Statistical analysis. Statistical analysis of binary distribution data over the 3-year field study showed that the odds of melon, pumpkin, and squash foliage being infected by the A. citrulli group I strain were $21.7,11.5$, and 22.1 times greater than the odds of watermelon foliage being infected by the group I strain, respectively $(P$ $<0.0001)$. However, the odds of melon, pumpkin, and squash foliage being infected by $A$. citrulli group I strain were not significantly different. More strikingly, the odds of melon fruits being infected by the group I A citrulli strain were 97.5 times greater than watermelon fruits being infected by the group I strain $(P<0.0001)$ (Table 5).

\section{DISCUSSION}

To rapidly determine if a BFB lesion from a plant sample was caused by a group I or II A. citrulli strain, we developed a group-specific duplex PCR-based assay. Primers for this assay were designed to amplify group-specific type III-secreted effectors (T3Es) (EckshtainLevi et al. 2014; Jiménez Guerrero et al. 2019). As expected, the two

TABLE 4. Temperature and precipitation for the Coastal Plain Experiment Station in Tifton GA during the field trials in 2017 to 2019

\begin{tabular}{|c|c|c|c|c|c|}
\hline Year & $\begin{array}{l}\text { Mean maximum } \\
\text { temperature }\left({ }^{\circ} \mathrm{C}\right)\end{array}$ & $\begin{array}{l}\text { Mean minimum } \\
\text { temperature }\left({ }^{\circ} \mathrm{C}\right)\end{array}$ & $\begin{array}{c}\text { Mean average } \\
\text { temperature }\left({ }^{\circ} \mathrm{C}\right)\end{array}$ & Total precipitation $(\mathrm{cm})$ & $\begin{array}{l}\text { Mean precipitation } \\
(\mathrm{cm}) / \text { day }\end{array}$ \\
\hline 2017 & 31.0 & 21.2 & 26.1 & 20.85 & 0.41 \\
\hline 2018 & 31.0 & 20.1 & 25.6 & 26.59 & 0.44 \\
\hline 2019 & 31.5 & 19.4 & 25.4 & 18.62 & 0.31 \\
\hline
\end{tabular}
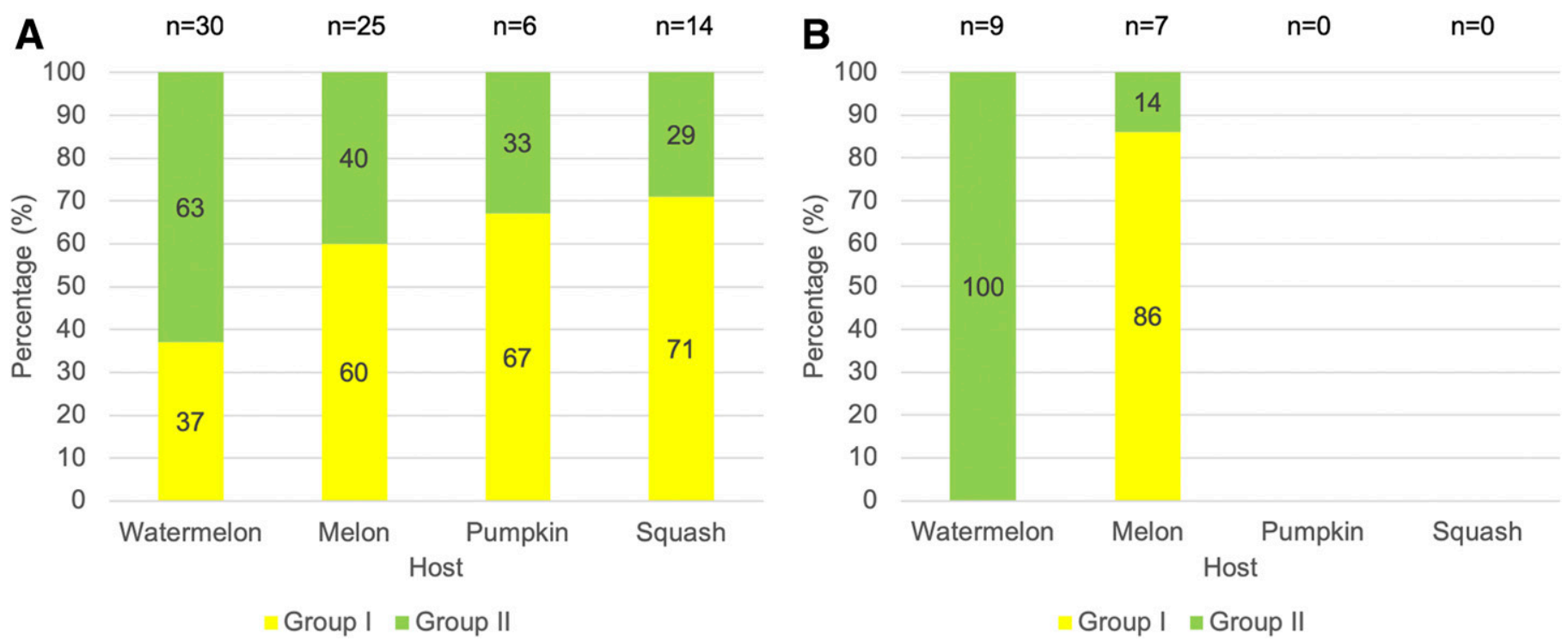

Fig. 2. The proportion of group I and II Acidovorax citrulli PCR-positives detected in symptomatic cucurbit A, foliage and $\mathbf{B}$, fruit samples from the 2017 field trial to investigate cucurbit host preference. The percentages of group I (yellow) and II (green) A. citrulli isolates are shown in the bar charts.

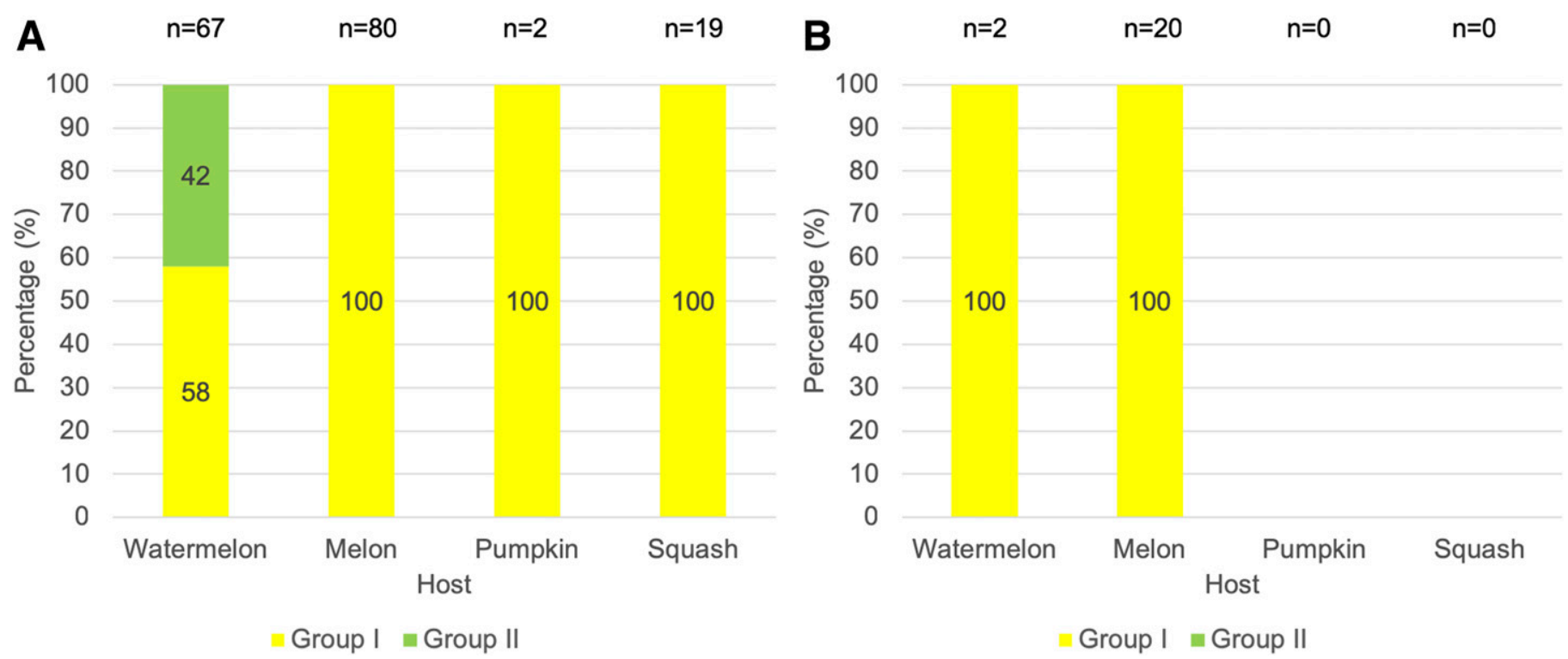

Fig. 3. The proportion of group I and II Acidovorax citrulli PCR-positives detected in symptomatic cucurbit A, foliage and B, fruit samples from the 2018 field trial to investigate cucurbit host preference. The percentages of group I (yellow) and II (green) A. citrulli isolates are shown in the bar charts. 
primer sets successfully discriminated group I and II strains. The detection sensitivity of this assay was low $\left(10^{6}\right.$ to $\left.10^{7} \mathrm{CFU} / \mathrm{ml}\right)$ relative to previously developed PCR-based assays for A. citrulli (Ha et al. 2009; Yang et al. 2019b). We are aware of the possibility of occurrence of false-negative results from the field samples. However, since our goal was to detect the presence of $A$. citrulli in well-established leaf and fruit lesions, and we expected pathogen populations in lesions to be relatively high (Yan et al. 2017; Zivanovic and Walcott 2017), we determined that the PCR assays were suitable for this study.

In 2017, we observed no substantial difference in the proportion of group I and II A. citrulli detected on the foliage of the four cucurbit species. Foliage from non-watermelon hosts (melon, pumpkin, and squash) showed slightly higher percentages $(60,67$, and $71 \%$, respectively) of samples infected with group I strains, while watermelon foliage showed a slightly higher percentage $(63 \%)$ of samples infected with group II strains. On the other hand, there appeared to be a difference in susceptibility of cucurbit fruits to different $A$. citrulli strains. More specifically, all watermelon fruit samples were infected by the group II strain, while all melon fruits, except one, were infected by the group I strain. The fruits of the pumpkin and squash cultivars tested did not appear to be susceptible to infection by the $A$. citrulli strains used under the tested conditions.
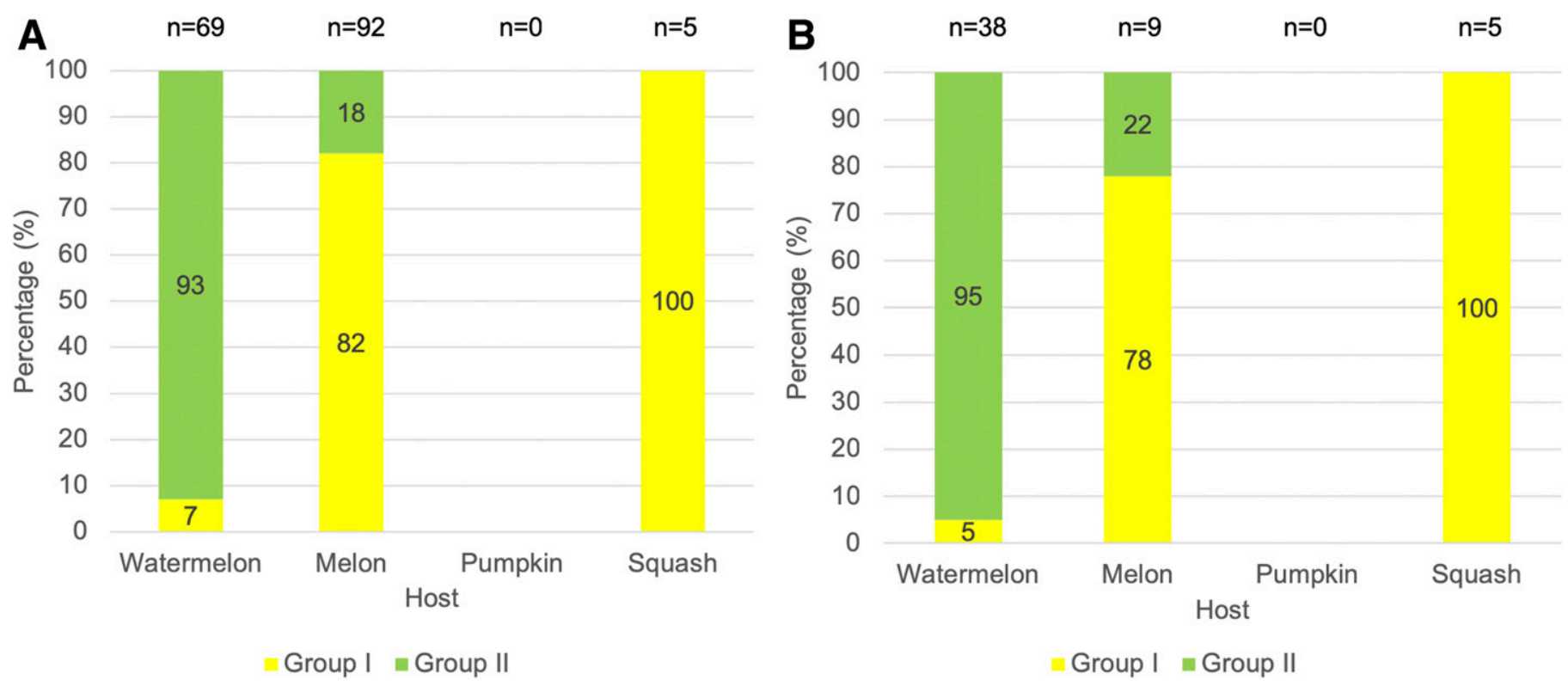

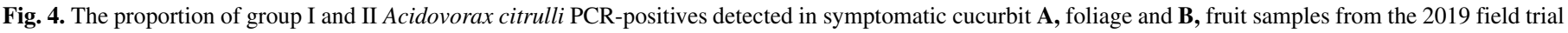
to investigate cucurbit host preference. The percentages of group I (yellow) and II (green) A. citrulli isolates are shown in the bar charts.

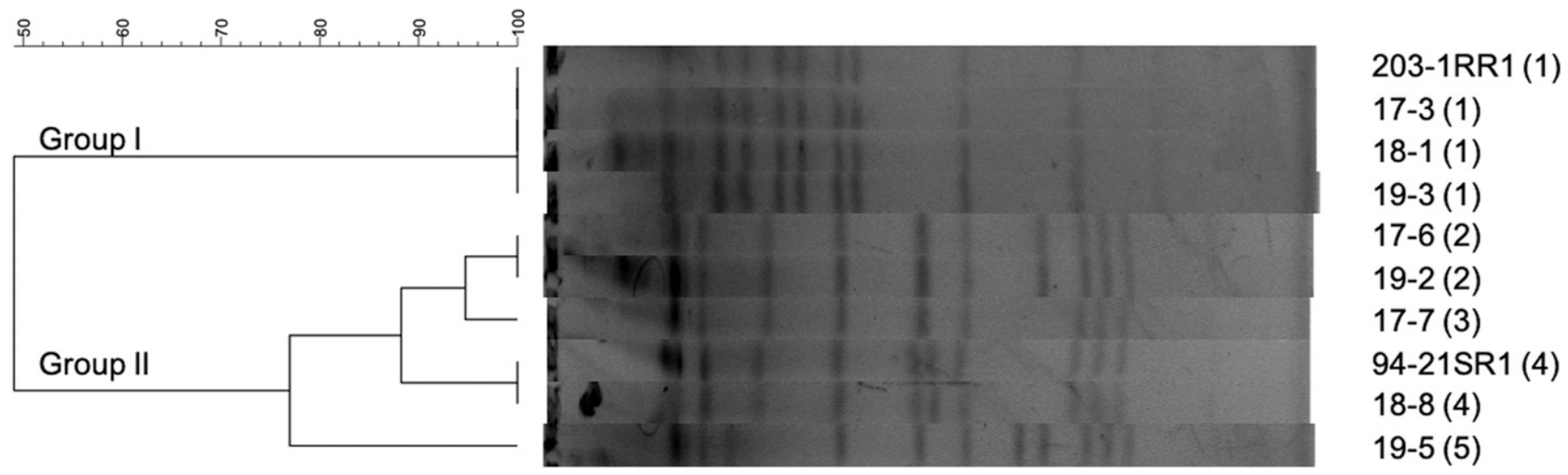

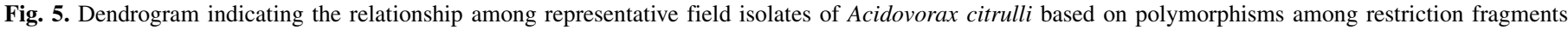

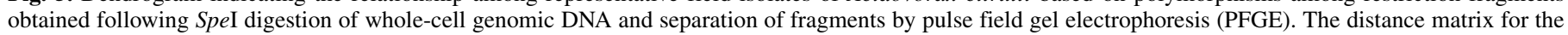

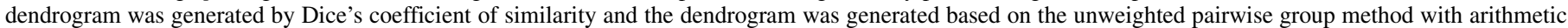
mean algorithm. The numbers in parentheses represent the PFGE types recovered from the field trials.

TABLE 5. Odds ratio estimates at cucurbit leaf and fruit levels from the output of GLIMMIX for binary distribution data over 3 years

\begin{tabular}{|c|c|c|c|c|c|c|}
\hline Tissue type & Host & Host & Odds ratio estimate & Degrees of freedom & \multicolumn{2}{|c|}{$95 \%$ confidence limits } \\
\hline Leaf & Melon & Watermelon & 21.662 & 401 & 11.48 & 40.88 \\
\hline Leaf & Pumpkin & Watermelon & 11.488 & 401 & 1.94 & 68.15 \\
\hline Leaf & Squash & Watermelon & 22.052 & 401 & 6.66 & 72.99 \\
\hline Fruit & Melon & Watermelon & 97.538 & 79 & 13.72 & 693.44 \\
\hline
\end{tabular}


Interestingly, the group II A. citrulli isolates recovered from the 2017 field samples differed from the inoculated strain, AAC94$21 \mathrm{SR} 1$, in that they were sensitive to streptomycin. SpeI-PFGE analysis of the 2017 group II field isolates revealed two distinguishable haplotypes, that were both different to the profile of AAC9421SR1. Based on this observation, we conclude that the group II isolates responsible for the $2017 \mathrm{BFB}$ epidemic originated from the local environment. On the other hand, the group I isolates recovered from the 2017 study were rifampicin-resistant and yielded identical PFGE profiles as the inoculum strain, AAC203-1RR1. Like other foliar Gram-negative bacteria, A. citrulli can survive epiphytically on host and nonhost plants under field conditions for certain time. These results suggest that group II isolates may be prevalent at the Tifton Vegetable Park farm, while group I isolates likely do not have localized sources of inoculum.

In 2018, group II A. citrulli strains were only observed on infected, symptomatic watermelon foliage. In contrast, we detected group I A. citrulli strains in leaf lesions of all cucurbit hosts, including watermelon. With regards to fruit samples, we only detected group I A. citrulli strains in BFB symptomatic melon and watermelon fruits. These data suggest that while the group II strain tested was specific to watermelon foliage, the group I strain could infect the foliage of all cucurbits tested under natural field conditions. As expected, the 2018 field isolates that were recovered had SpeI-PFGE profiles that were identical to their respective inocula. However, since we did not recover AAC94-21SR1 from infected watermelon fruits, we suspected this group II strain was weakly virulent under tested conditions. We also suspected that the local field isolate from the 2017 field trial was more virulent than AAC94-21SR1 under field conditions. Since this strain (called 176) occurred naturally, we considered that it might better allow us to test our hypothesis regarding cucurbit host preference of $A$. citrulli groups under field conditions. Hence, for the 2019 field study, we included both AAC94-21SR1 and the field isolate 17-6 as group II inocula.

For the 2019 field study, we observed a substantial difference in the proportion of group I and II A. citrulli strains detected on the foliage of the four cucurbit species. While all pumpkin leaf samples were negative for A. citrulli, symptomatic melon and squash leaf samples were infected with high percentages (82 and 100\%, respectively) of group I strains. Additionally, 93\% of the infected watermelon leaf samples were infected with group II strains. Unlike data from the 2017 and 2018 studies, these data strongly suggested A. citrulli host preference on cucurbit foliage, with the group II strains showing a strong preference for watermelon and the group I strain showing a strong preference for melon and squash foliage. It is possible that the specific microclimate environment during the 2019 field trial, with the combination of the used strains, resulted in a stronger host preference on cucurbit foliage in 2019.

In 2019, the A. citrulli strains showed strong host preference on the fruits of different cucurbits. More specifically, $95 \%$ of the symptomatic watermelon fruits were infected with the group II strains, while $78 \%$ of melon fruits were infected with the group I strain. Interestingly, for the first time in 2019, we observed natural BFB squash fruit infection and $100 \%(5 / 5)$ of these fruits were infected with the group I strain. Remarkably, lesions of all five infected squash fruits were associated with injury caused by pickleworms (Diaphania nitidalis). We speculate that wounds created by insects possibly facilitated the entry of $A$. citrulli into fruit tissues. We observed pickleworm damage on melon fruits in 2017 and 2018 trials, and on melon, squash, and pumpkin fruits in 2019 trials. Despite this, throughout this study, pumpkin fruits did not develop BFB symptoms. Hence, we suspect that it is likely that insect damage increases the likelihood of BFB fruit infection for some cucurbit fruits.

Hopkins and Thompson (2002b) reported that in a field study using a single $A$. citrulli group II strain, fruit symptoms were not observed on the fruits of acorn squash cultivar Tay Belle, pumpkin cultivar Ichabod, or butternut squash cultivar Butterboy. However, they observed a few small lesions on zucchini squash cultivar Elite 828 and yellow squash cultivar Crescent in 1 of 2 years (Hopkins and Thompson 2002b). Based on these results and our direct observations, we conclude that under natural field conditions, pumpkin and squash fruits are at low risk for A. citrulli infection relative to watermelon and melon fruits. However, A. citrulli infection of pumpkin fruits was reported to occur in a commercial field in Georgia in 1998 (Langston et al. 1999). To date, only watermelon and melon cultivars and germplasm collections have been extensively screened for BFB resistance (Bahar et al. 2009; Carvalho et al. 2013; Hopkins and Thompson 2002a; Hopkins et al. 1993; Wechter et al. 2011). It would be interesting to screen pumpkin germplasm for BFB resistance.

Host preference within a pathogen species has been demonstrated in other pathosystems. For example, Erwinia tracheiphila, the causal agent of bacterial wilt of cucurbits, infects two genera of cucurbit crop plants, Cucurbita spp. (pumpkin and squash) and Cucumis spp. (muskmelon and cucumber) (Rojas et al. 2015). Based on whole genome sequence analysis, Shapiro et al. (2018) found that $88 \mathrm{E}$. tracheiphila strains from different geographic ranges were divided into three clusters, Et-melon, Et-C1, and Et-C2. Strains from the three clusters were detected in field-infected cucumber plants, while muskmelon was infected only by the Etmelon strains, and squash was only infected by the Et-C1 and Et-C2 strains (Shapiro et al. 2018). E. tracheiphila strains also varied in their virulence in a host-dependent pattern. The authors suggested that the introduced and highly susceptible cucumber cultivars were driving E. tracheiphila lineage diversification.

Determining the host preference of a pathogen is important, as it helps to estimate the risk of disease outbreaks. While previous anecdotal observations suggested differences in cucurbit host preference of group I and II A. citrulli strains, no empirical data were generated to directly test this hypothesis under field conditions. In the current study, we demonstrated that the two A. citrulli groups differed in their ability to infect the foliage of different cucurbit species. More importantly, we demonstrated that this host preference manifested itself more strongly in cucurbit fruit tissues. We observed differential susceptibility of host tissue types (foliage versus fruit) to A. citrulli strains. Importantly, most of the fundamental investigations on model plant pathogenic bacterial species, such as Pseudomonas syringae pv. tomato, have involved foliar tissue inoculations (Xin et al. 2018). Fruit tissue represents a unique niche for plant and human pathogens that may require different adaptations compared with other host tissue types. Therefore, exploring pathogen-fruit interactions has biological and economic significance for improving disease management. From an economic standpoint, fruit infection is the most important phase of BFB epidemiology. Studying the mechanisms of fruit infection is also important for improving BFB management. A. citrulli cells have been shown to penetrate watermelon (Frankle and Hopkins 1993) and melon (Silva Neto et al. 2006) fruits via stomata. It would be interesting to test the factors that permit or promote entry of $A$. citrulli into plant tissues to initiate infection, and to investigate differences in the mechanisms of fruit infection by different $A$. citrulli strains in combination with fruits from distinct cucurbit crops.

Elucidating variations in virulence and host preference determinants among A. citrulli strains could set the stage for detection of genetic markers of host resistance. Currently, no BFB-resistant cucurbit cultivars are commercially available. Thus, in addition to field studies to investigate $A$. citrulli host preference, it is necessary to understand the genetic factors that differentiate group I and II strains and to determine their roles in virulence and host preference. Eckshtain-Levi et al. (2014) reported that three effectors in the XopJ family were present in group II strains, but were absent or nonfunctional in group I strains. In addition, Jiménez Guerrero et al. (2019) identified 10 unique T3Es that were present in the A. citrulli 
group I strain M6, but absent in the group II strain AAC00-1. The variability in T3E arsenals between A. citrulli group I and II strains may contribute to the differences in the host-preferential association between the groups. Despite this, more research is needed to test this hypothesis and to understand the mechanisms of host preference of A. citrulli. The current study demonstrates host preference of A. citrulli under natural field conditions, but additional research is critical for the development of more effective strategies for BFB management.

\section{ACKNOWLEDGMENTS}

We thank Michael Foster for field plot management, Shufang Tian and Li Wang for disease scouting, and Brian Kvitko and Shavannor Smith for technical assistance.

\section{LITERATURE CITED}

Bahar, O., Kritzman, G., and Burdman, S. 2009. Bacterial fruit blotch of melon: Screens for disease tolerance and role of seed transmission in pathogenicity. Eur. J. Plant Pathol. 123:71-83.

Burdman, S., Kots, N., Kritzman, G., and Kopelowitz, J. 2005. Molecular, physiological, and host-range characterization of Acidovorax avenae subsp. citrulli isolates from watermelon and melon in Israel. Plant Dis. 89:1339-1347.

Burdman, S., and Walcott, R. 2012. Acidovorax citrulli: Generating basic and applied knowledge to tackle a global threat to the cucurbit industry. Mol. Plant Pathol. 13:805-815.

Carvalho, F. C., Santos, L. A., Dias, R. C., Mariano, R. L., and Souza, E. B. 2013. Selection of watermelon genotypes for resistance to bacterial fruit blotch. Euphytica 190:169-180.

Eckshtain-Levi, N., Munitz, T., Živanović, M., Traore, S. M., Spröer, C., Zhao, B., Welbaum, G., Walcott, R., Sikorski, J., and Burdman, S. 2014. Comparative analysis of type III secreted effector genes reflects divergence of Acidovorax citrulli strains into three distinct lineages. Phytopathology 104: 1152-1162.

Feng, J., Schuenzel, E. L., Li, J., and Schaad, N. W. 2009. Multilocus sequence typing reveals two evolutionary lineages of Acidovorax avenae subsp. citrulli. Phytopathology 99:913-920.

Frankle, W., and Hopkins, D. 1993. Ingress of the watermelon fruit blotch bacterium into fruit. Plant Dis. 77:1090-1092.

Ha, Y., Fessehaie, A., Ling, K. S., Wechter, W. P., Keinath, A. P., and Walcott, R. R. 2009. Simultaneous detection of Acidovorax avenae subsp. citrulli and Didymella bryoniae in cucurbit seedlots using magnetic capture hybridization and real-time polymerase chain reaction. Phytopathology 99: 666-678.

Hopkins, D., Thompson, C., and Elmstrom, G. 1993. Resistance of watermelon seedlings and fruit to the fruit blotch bacterium. HortScience 28: 122-123.

Hopkins, D. L., and Thompson, C. M. 2002a. Evaluation of Citrullus sp. germ plasm for resistance to Acidovorax avenae subsp. citrulli. Plant Dis. 86: 61-64.

Hopkins, D. L., and Thompson, C. M. 2002b. Seed transmission of Acidovorax avenae subsp. citrulli in cucurbits. HortScience 37:924-926.

Isakeit, T., Black, M. C., and Jones, J. B. 1998. Natural infection of citronmelon with Acidovorax avenae subsp. citrulli. Plant Dis. 82:351.

Jiménez Guerrero, I., Pérez-Montaño, F., da Silva, G. M., Wagner, N., Shkedy, D., Zhao, M., Pizarro, L., Bar, M., Walcott, R., and Sessa, G. 2019. Show me your secret(ed) weapons: A multifaceted approach reveals novel type III-secreted effectors of a plant pathogenic bacterium. bioRxiv 679126 .

King, E. O., Ward, M. K., and Raney, D. E. 1954. Two simple media for the demonstration of pyocyanin and fluorescin. J. Lab. Clin. Med. 44:301-307.

Kõressaar, T., Lepamets, M., Kaplinski, L., Raime, K., Andreson, R., and Remm, M. 2018. Primer3_masker: Integrating masking of template sequence with primer design software. Bioinformatics 34:1937-1938.
Langston, D., Jr., Walcott, R., Gitaitis, R., and Sanders, F., Jr. 1999. First report of a fruit rot of pumpkin caused by Acidovorax avenae subsp. citrulli in Georgia. Plant Dis. 83:199.

Latin, R., and Rane, K. 1990. Bacterial fruit blotch of watermelon in Indiana. Plant Dis. 74:331.

Martin, H., and Horlock, C. 2002. First report of Acidovorax avenae subsp. citrulli as a pathogen of Gramma in Australia. Plant Dis. 86:1406.

Martin, H., O’Brien, R., and Abbott, D. 1999. First report of Acidovorax avenae subsp. citrulli as a pathogen of cucumber. Plant Dis. 83:965.

O'Brien, R., and Martin, H. 1999. Bacterial blotch of melons caused by strains of Acidovorax avenae subsp. citrulli. Aust. J. Exp. Agric. 39:479-485.

Rojas, E. S., Batzer, J. C., Beattie, G. A., Fleischer, S. J., Shapiro, L. R., Williams, M. A., Bessin, R., Bruton, B. D., Boucher, T. J., and Jesse, L. C. 2015. Bacterial wilt of cucurbits: Resurrecting a classic pathosystem. Plant Dis. 99:564-574.

Shapiro, L. R., Paulson, J. N., Arnold, B. J., Scully, E. D., Zhaxybayeva, O., Pierce, N. E., Rocha, J., Klepac-Ceraj, V., Holton, K., and Kolter, R. 2018. An introduced crop plant is driving diversification of the virulent bacterial pathogen Erwinia tracheiphila. MBio 9:e01307-e01318.

Silva, G. M., Souza, R. M., Yan, L., Junior, R. S., Medeiros, F. H., and Walcott, R. R. 2016. Strains of the group I lineage of Acidovorax citrulli, the causal agent of bacterial fruit blotch of cucurbitaceous crops, are predominant in Brazil. Phytopathology 106:1486-1494.

Silva Neto, E. B., Silveira, E. B., Mariano, R. L., Nogueira, N. L., Rossi, M. L., and Santos, L. A. 2006. Penetration and colonization of Acidovorax avenae subsp. citrulli in leaves, seeds and fruits of melon type yellow. Fitopatol. Bras. 31:84-88.

Somodi, G. C., Jones, J., Hopkins, D., Stall, R., Kucharek, T., Hodge, N., and Watterson, J. 1991. Occurrence of a bacterial watermelon fruit blotch in Florida. Plant Dis. 75:1053-1056.

Walcott, R. R., Fessehaie, A., and Castro, A. C. 2004. Differences in pathogenicity between two genetically distinct groups of Acidovorax avenae subsp. citrulli on cucurbit hosts. J. Phytopathol. 152:277-285.

Walcott, R. R., Langston, D. B., Sanders, F. H., and Gitaitis, R. D. 2000. Investigating intraspecific variation of Acidovorax avenae subsp. citrulli using DNA fingerprinting and whole cell fatty acid analysis. Phytopathology 90:191-196.

Wall, G., and Santos, V. 1988. A new bacterial disease of watermelon in the Mariana Islands. Phytopathology 78:1-9.

Webb, R. E., and Goth, R. W. 1965. A seedborne bacterium isolated from watermelon. Plant Dis. Rep. 49:818-821.

Wechter, W. P., Levi, A., Ling, K.-S., Kousik, C., and Block, C. C. 2011. Identification of resistance to Acidovorax avenae subsp. citrulli among melon (Cucumis spp.) plant introductions. HortScience 46:207-212.

Xin, X.-F., Kvitko, B., and He, S. Y. 2018. Pseudomonas syringae: What it takes to be a pathogen. Nat. Rev. Microbiol. 16:316.

Yan, L., Baishi, H., Chen, G., Zhao, M., and Walcott, R. R. 2017. Further evidence of cucurbit host specificity among Acidovorax citrulli groups based on a detached melon fruit pathogenicity assay. Phytopathology 107 : 1305-1311.

Yan, S., Yang, Y., Wang, T., Zhao, T., and Schaad, N. W. 2013. Genetic diversity analysis of Acidovorax citrulli in China. Eur. J. Plant Pathol. 136:171-181.

Yang, R. Z., Santos-Garcia, D., Pérez Montaño, F., Zhao, M., Jimenez Guerrero, I., Da Silva, G. M., Rosenberg, T., Chen, G., Plaschkes, I., and Morin, S. 2019a. Complete assembly of the genome of an Acidovorax citrulli strain reveals a naturally occurring plasmid in this species. Front. Microbiol. 10: 1400 .

Yang, Y. W., Zhao, M., Zhang, L., Qiao, P., Bai, X., Zhang, X., Walcott, R., Guan, W., and Zhao, T. 2019b. Development of a multiplex PCR assay based on the pilA gene sequences to detect different types of Acidovorax citrulli. J. Microbiol. Methods 158:93-98.

Zhao, M., and Walcott, R. 2018. Acidovorax citrulli: history, epidemiology, and management of bacterial fruit blotch of cucurbits. Pages 39-57 in: Plant Pathogenic Acidovorax Species. S. Burdman and R. Walcott, eds. American Phytopathological Society, St. Paul, MN.

Zivanovic, M., and Walcott, R. R. 2017. Further characterization of genetically distinct groups of Acidovorax citrulli strains. Phytopathology 107:29-35. 